\title{
SUSTAINABLE CONSUMPTION AND PRODUCTION FROM A STRATEGIC ACTION FIELD PERSPECTIVE
}

\author{
Érico Luciano Pagotto \\ Sylmara Lopes Francelino Gonçalves-Dias
}

${ }^{I}$ Ecologist. He was awarded an MSc in Social Change and Political Participation and PhD in Sustainability by the University of São Paulo and is a Professor at the Fatec Jacarei and Anhanguera University, São José dos Campos. São José dos Campos/SP - Brasil

"I PhD in Administration, awarded by the Getulio Vargas Foudation's São Paulo School of Business Administration, and $a \mathrm{PhD}$ in Environmental Sciences awarded by the University of São Paulo. She is a Professor at the School of Arts, Sciences and Humanities at the University of São Paulo São Paulo/SP - Brasil
Abstract: This article analyzes the process of construction of public policies of sustainable production and consumption in Brazil after the country joined the Marrakesh Process in 2003. Based on the strategic action fields perspective, we analyze the emergence of this field, its characteristics and their status through the collective action of their main social actors, their actions, interests and disputes. Empirical material for analysis included plans developed during the period, minutes of the meeting, documents submitted to the public consultation, responses provided by civil society after the consultation, as well as in-depth interviews. Evidence shows that a series of obstacles have been delaying further advances of the politics of sustainable production and consumption due to disputes between incumbents and challengers.

Keywords: sustainability, policies, consumption, strategic action fields

Original Article

DOI: http://dx.doi.org/10.1590/1809-4422asoc20190027r1vu2020L4AO 


\section{Introduction}

The discussion about the limits to the capacity of ecosystems to sustain current levels of consumption and production is particularly relevant today and has now become sector-wide. In academia, for example, the polysemies of sustainability and its outcomes have fueled debate over its theoretical underpinnings and practical implications (BOLIS et al., 2014; PEREY, 2015; SILVA JUNIOR; FERREIRA; LEWINSOHN, 2015). In strategic business planning, the recurring challenge posed by sustainability is reengineering to produce more with less in order to save resources, boost profit, and meet market demands. Meanwhile, in the streets the population grapple with the phantom of shortages - of water, energy, or consumer goods - caused not only by administrative deficiencies, but also the impact of the of the current economic model on the availability of inputs. At the epicenter of crises and shortages, governments continue to face the challenge of managing increasingly complex problems with an increasingly minimal structure - not only in terms of infrastructure, but also, and above all, in terms of power. Consumption and production are two sides of a tradeoff between society and the environment. The trouble is, though, that the impact of human activities on the Planet's resources ("ecological footprint") has exceeded its capacity for renewal ("biocapacity") since the 1970s (CAVALCANTI, 2012; WWF, 2014).

Research and policy directed at so-called "sustainable consumption and production"(SCP) has emerged as an alternative response to the socioenvironmental crisis, acknowledging the problem and seeking to better understand the possibilities open for rebalancing the accounts (LOREK, BARBER, ONTHANK, 2013). The literature on this topic has become increasingly vast and specialized. Nevertheless, the definition of SCP is still open to debate and subject to varying concepts, approaches, and worldviews proffered across distinct and often opposing fields (JACKSON;MICHAELIS, 2003; PORTILHO, 2005; MONT;PLEPYS, 2007; GONÇALVES-DIAS, MOURA; HOYOS, 2011; WANG et al., 2019).

However, there is consensus on certain aspects; namely that -and perhaps the main point of departure for debate - current patterns of natural resource extraction, production, consumption, and waste disposal are environmentally unsustainable (THØGERSEN, 2014). Moreover, there is an understanding that increasing social and environmental impacts throughout the supply chain are intrinsically linked to postmodern lifestyles and the prevailing global model of economic growth (STERN, 2000).

These differing views tend to converge on a central point - that SCP is a complex phenomenon that requires a more integrative epistemological approach that extends beyond traditional disciplinary taxonomies, mobilizing knowledge and methods that are not limited to just a few areas (LOREK; BARBER; ONTHANK, 2013). As a social phenomenon of great magnitude deeply rooted in the very foundations of civilization, it is also clear that SCP involves different actors - each with distinct roles, responsibilities, and reaches - and that possible alternative solutions call for the mobilization of key actors from civil society, the private sector, and the state (DOLAN, 2002; SEYFANG, 2004; SCHOON; SEATH; JACKSON, 2013). 
The crisis caused by the imbalance between natural resource extraction and renewal has gained growing recognition at UN international conferences since the beginning of the 1970s. Agenda 21 (established in 1992), the Marrakech Process (launched in 2003), and the Sustainable Development Goals (adopted in 2015 and set to be achieved by 2030) are just some examples of agreements that come with the commitment to develop SCP public policy to which Brazil is signatory.

With this in mind, this study investigates the development of SCP policies in Brazil and asks who actually develops these measures and whose interests they serve. To this end, the aim of the present study was to explore and understand the dynamics of the social actors that make up the SCP field by analyzing Brazil's engagement in international SCP agreements.

The remainder of the article is organized into five sections starting with a discussion of methodological considerations. The next section provides a historical overview of the development of SCP policies in Brazil, followed by a discussion of the results of the analysis of the discourse of the social actors involved in these policies. Finally, in the last section we present some final considerations.

\section{Methodological considerations}

This study adopts a theoretical and methodological approach based around three core categories described by Maxwell (2012): the substantive category, which refers to the object of study, conceptual category, relating to the conceptual and theoretical bases for the research and methodological domain, referring to the operationalization of the research question.

With regard to the object of study - in this case SCP policies - various authors have studied and attempted to better understand the notion of SCP, its ramifications (REISCH; THØGERSEN, 2015; LIU et al., 2017), and policies shaped around the concept (SEYFANG, 2004; DRIESSEN et al., 2012; KALMYKOVA et al., 2016; BARBER, 2007). However, there are few studies on this topic in Brazil (PORTILHO; RUSSO, 2008; GONÇALVES-DIAS; TEODÓSIO, 2012; PAGOTTO; GONÇALVES-DIAS, 2018).

With respect to the conceptual category, we opted for the theory of strategic action fields (SAF), which allows us to understand the process of field emergence and transformation by analyzing the collective action of social actors and the state (FLIGSTEIN; McADAM, 2012). The SAF perspective depends on the context in which the field is embedded. Understanding the status of a field (stable, emergent, in crisis, or restructuring) is important because it allows us to characterize resource distribution among actors, their organization (more cooperative or more hierarchical), the level of shared understanding about the role of the field and the position of each actor, as well as the degree of consensus and institutional recognition among the actors in the field (FLIGSTEIN; McADAM, 2012). Thus, for a field to be established, some degree of agreement is needed among the actors in relation to the field, its functioning, participants, and each actors' role. A number of authors have successfully applied field theory to the study of public policy 
and sustainability (GOLDSTONE; USEEM, 2012; MOULTON; SANDFORT, 2017).

Previous studies have demonstrated SAF theory's potential for understanding the dynamics of state and non-state actors in action and the implications of these movements. In a study investigating policies directed at the consumption and production of open government data, Barbalho (2014) noted that the disputes over narrative that tend to dominate the substance of agreements that make for stability in the field provide an extensive agenda for negotiation and action.

With regard to environmental policy, other studies have provided insights into the formation of strategic action fields. Godoy (2011), for example, demonstrated how SAF theory can be used to analyze environmental policy formulation. In a case study of the workings of a municipal environmental council in Brazil, the author noted that incumbent groups tend to obstruct the advance of more progressive agendas, wielding political and financial influence over other actors and internal governance units. According to FLIGSTEIN and McADAM (2012), governance units are arrangements that are internal to the field and are charged with overseeing compliance with field rules, helping to maintain order and facilitating the functioning and reproduction of the field.

SAF theory has also been used to study the dynamics of social actors in national bodies such as the National Biodiversity Commission (MANDAI, 2017) and National Confederation of Tourism (ALENCAR; REYES JUNIOR, 2017), which could be characterized as fields in dispute. Other authors have used SAF theory to study aspects of waste management (RAM et al., 2017; CANDIDO; SOULÉ; SACOMANO NETO, 2018; FERREIRA, 2018, CSEH, 2019)

FLIGSTEIN and McADAM (2012) suggest that a field can contain or be embedded in other fields, resembling Russian dolls. From this perspective, sustainability may be considered a field whose internal governance rules come about by interaction between its actors and the legitimization of public policy. In Brazil, such policies include the National Water Resources Policy, National Waste Policy, National Environmental Education Policy, and SCP policies.

With regard to the methodological category, the operation of field theory entails demonstrating the existence of the field, its actors and characteristics and the resulting dynamics. We therefore opted for triangulation between documentary research (CALADO; FERREIRA, 2009), participant observation (BELAW et al., 2008), and in-depth interviews (DUARTE, 2006), the elements of which were analyzed drawing upon techniques used in Sociological Discourse Analysis (GODOI; COELHO; SERRANO, 2014).

Various authors have demonstrated the applicability of Sociological Discourse Analysis (SDA) for analyzing sustainability discourses (JONQUERES, 2008; COELHO; GODOI, 2010; COELHO et al., 2012; BORCHARDT; SIENA, 2016). SDA "consists of the critical reconstruction of their meaning [of discourses] linked to the historical contextualization of their enunciation" (RODRÍGUEZ VICTORIANO, 2003, p. 25). Conde (2009) claims that this analytical technique provides a more complete picture of power relations, considering those who emit discourses and their sociohistorical context. The practical application of SDA involves a logical and systematic process of construction 
and reconstruction departing from an initial investigation of the text and culminating in analysis in the proper sense of the word, encompassing narrative configuration and semantic spaces and identifying social subjects, what is discussed and its meaning, and what is at stake (CONDE, 2009). Godoi; Mastella; Uchôa (2018) highlight that this process differs from neopositivist models, which begin with analysis and culminate in interpretation.

\section{The history of SCP policy in Brazil}

The construction of SCP policy in Brazil dates back to 1992 (Figure 1) and the signing of the global action program, Agenda 21. A comprehensive document of almost 500 pages divided into 40 chapters, Agenda 21 states that so-called "developed" countries should take the lead in the pursuit of sustainable consumption patterns - reinforcing what it calls the "the transfer of environmentally sound technologies to developing countries" - and proposes "sustainable economic growth" as a means of achieving "sustainable development” (CNUMAD, 1995).

Figure 1: main milestones in the construction of SCP policy in Brazil

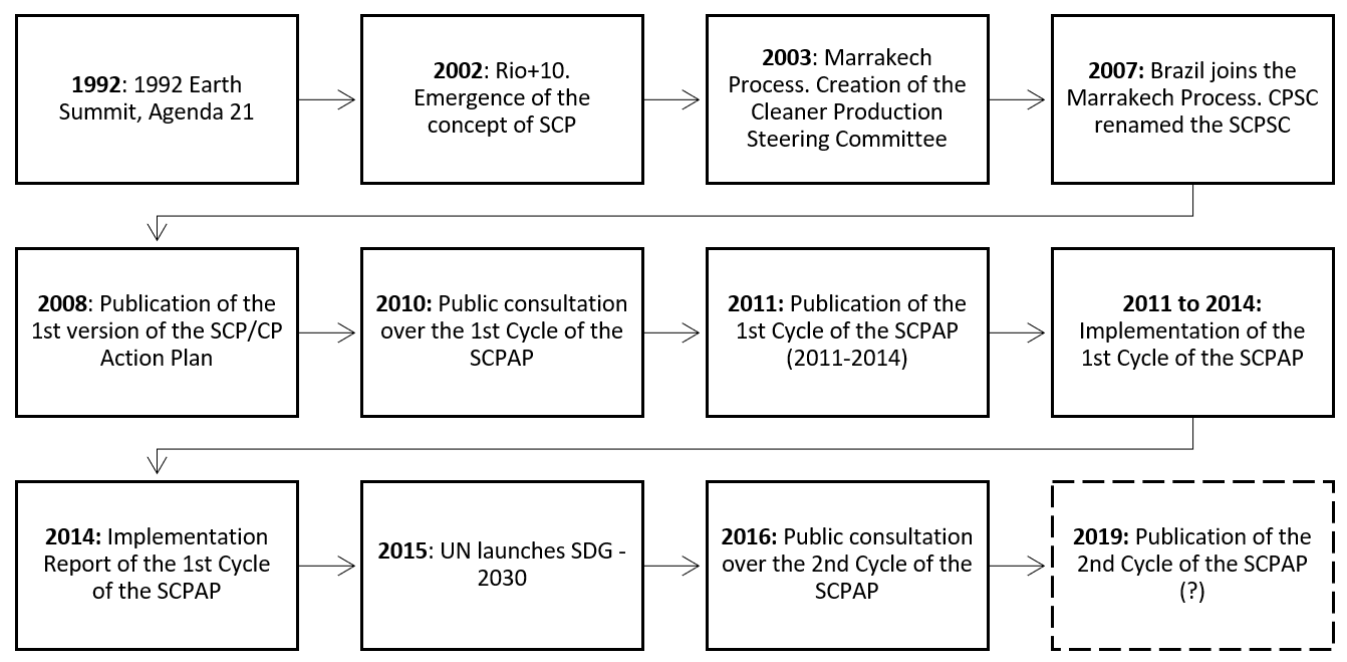

Source: authors' elaboration ${ }^{1}$.

In 2002, the term "sustainable consumption and production" was proposed at the "Rio +10 " Summit and in the following year the UN launched the "Marrakech Process", an international initiative to strengthen the formulation of SCP policies. For the signatory countries, this entailed the elaboration of national SCP actions plans (SCPAP).

In 2007, Brazil joined the Marrakech Process and the Ministry of the Environment (MoE) changed the name of the "Cleaner Production Steering Committee - CPSC", 
created in 2003, to the "SCP Steering Committee - SCPSC". The name change brought about a shift in focus from cleaner production, geared towards manufacturing supply chains and business competitiveness, to SCP, which incorporates the idea of minimizing environmental and social impacts and reducing health and environmental risks.

In 2008, the government published the first version of the national SCPAP, which, fruit of the work of the CPSC, maintained the focus on CP. Over the next few of years, the plan was revised and in 2010 the MoE launched a public consultation over the preliminary version of the 1st Cycle of the Plan. The final version of the Plan was published in 2011 (MMA, 2011), presenting a schedule of activities to be implemented between 2011 and 2014.

In 2014, the government published the Implementation Report of the 1st Cycle of the SCPAP (MMA, 2014), presenting a general overview of the incorporation of the SCP agenda across sectors and by the government. Box 1 shows some examples of the initiatives that the report presents as examples of incorporation of the SCP agenda by the public and private sectors.

Box 1: Examples of initiatives highlighted by the SCPAP Implementation Report

\begin{tabular}{|c|c|c|}
\hline Sector & SCP Actions & $\begin{array}{l}\text { Government body } \\
\text { responsible }\end{array}$ \\
\hline \multirow{5}{*}{$\begin{array}{l}\text { Education for Sustainable } \\
\text { Consumption }\end{array}$} & Provision of distance learning courses on SCP & $\mathrm{MoE}$ \\
\hline & $\begin{array}{l}\text { Creation of the Environmental Education and Family } \\
\text { Agriculture Program }\end{array}$ & MoE \\
\hline & Creation of the EducaRES Platform addressing waste & $\mathrm{MoE}$ \\
\hline & Creation of the Sustainable Schools PPDE & MEC \\
\hline & 4th National Environment Conference & $\mathrm{MoE} / \mathrm{MEC}$ \\
\hline \multirow{4}{*}{$\begin{array}{l}\text { Sustainable Public Procu- } \\
\text { rement }\end{array}$} & $\begin{array}{l}\text { Inclusion of regulation of sustainability criteria for sustai- } \\
\text { nable procurement }\end{array}$ & $\mathrm{MP}$ \\
\hline & $\begin{array}{l}\text { Creation of the Interministerial Commission for Sustai- } \\
\text { nability in Public Administration }\end{array}$ & Federal Government \\
\hline & $\begin{array}{l}\text { Publication of normative instruments sustainable logis- } \\
\text { tics, efficient energy use, and green TI }\end{array}$ & $\mathrm{MP}$ \\
\hline & $\begin{array}{l}\text { Creation of a catalogue of sustainable products for public } \\
\text { procurement }\end{array}$ & MP \\
\hline $\begin{array}{l}\text { Environmental Agenda in } \\
\text { Public Administration }\end{array}$ & Incentives for the A3P Network & MoE/intersectoral \\
\hline Increase in Recycling & Cites the National Waste Policy and ramifications & Various \\
\hline
\end{tabular}


Sector

SCP Actions

\begin{tabular}{ll|l} 
& $\begin{array}{l}\text { Describes programs adopted by retailers to promote } \\
\text { eco-efficiency, traceability, waste management, emission } \\
\text { inventories, certifications, sustainability reports, awards, } \\
\text { sectoral agreements, voluntary agreements and actions }\end{array}$ & $\begin{array}{l}\text { Retail sector and } \\
\text { respective professio- } \\
\text { nal associations }\end{array}$ \\
\cline { 2 - 4 } Suble Retail & $\begin{array}{l}\text { SCPAP mentions the following federal government } \\
\text { actions: Brazilian Habitat Quality and Productivity Pro- } \\
\text { gram, My House My Life Program (2009), Procel Edifica } \\
\text { (1985), Blue House Seal promoted by the national bank }\end{array}$ & $\begin{array}{l}\text { Cainistry of Cities, } \\
\text { private sector }\end{array}$ \\
\hline Caixa Economic (2010) and voluntary private sector \\
initiatives
\end{tabular}

Source: authors' elaboration based on MMA, 2011.

In 2015, the UN published the Sustainable Development Goals (SDGs 2030) and in 2016, based on these goals, the MoE launched a public consultation over the 2nd Cycle of the SCPAP (2016 to 2020). The final version of the 2 nd Cycle had yet to be published at the date of publication of this article and is likely not to be published given the change in government.

\subsection{The SCP in Brazil and its actors}

Prepared by the federal government, the aim of the SCPAP is to encourage medium and long-term initiatives and actions that promote a shift in the consumption and production paradigm in Brazilian society (MMA, 2011). The preparation of the SCPAP is the responsibility of the $\mathrm{MoE}$, here considered the main state actor in the field. The Plan is coordinated by the Department of Sustainable Consumption and Production (DSCP), which answers to the Secretariat for Institutional Articulation and Environmental Citizenship (SIAEC). 
The MoE receives technical and financial support for the implementation of the SCPAP from the United Nations Environment Program - UNEP (responsible for Rio + 20) and United Nations Development Program - PNUD (responsible for the SDGs 2030). Part of the resources provided by the UNEP was used to hire specialist consultancy services and implement projects in areas considered priorities by the Plan: Education for Sustainable Consumption, Sustainable Public Procurement, the Environmental Agenda in Public Administration (A3P), and Waste and Sustainable Construction.

The MoE created a National SCP Steering Committee made up of federal government organizations, the UNEP, private sector organizations, unions, research institutions, and civil society organizations. These actors and the cycles they participated in are shown in Box 2. It can therefore be said that these actors recognize the SCP, its role, and the participation of the state as an important articulating element and that the Steering Committee is an important internal governance unit, as described by FLIGSTEIN and McADAM (2012).

\section{Box 2: Actors participating in the National SCP Steering Committee}

\section{State actors}

- Ministries (acronyms in Portuguese):

- of the Environment (MMAE)

- of Agriculture (MAPA)*

- of Science, Technology, and Innovation (MCTI)

- of Development, Industry, and

Foreign Trade (MDIC)

- of Mines and Energy (MME)

- of Cities (Mcidades)

- of Finance (MF)

- of Planning (MP)*

- of Agrarian Development (MDA)*

- of Transport (MT)*

- Finance Sector:

Central Bank of Brazil (BACEN)*

National Development Bank (BN-

DES)

- Research Institutions:

The National Institute of Metrology, Standardization and Industrial Quality (INMETRO)*

Brazilian Institute of Geography and Statistics (IBGE)*

\section{Non-state actors}

Private sector organizations (acronyms in Portuguese):

- Brazilian Business Council for Sustainable Development (CEBDS)

- National Confederation of Industry (CNI)

- National Service for Industrial Learning (SENAI)

- Micro and Small Business Support Service (SEBRAE)

- Business Recycling Commitment (CEMPRE)

- National Confederation of Commerce (CNC)

- Brazilian Life Cycle Association (ABCV)*

Universities:

- Getúlio Vargas Foundation (FGV)

- Civil society organizations:

Instituto Akatu

Instituto Ethos

Brazilian Institute for Consumer Protection (IDEC)

- Professional associations:

Unified Workers' Central (CUT)

Brazilian Institute of Independent Auditors (IBRACON)*

Brazilian Association of Technological Research Institutions

(ABIPTI)

- ONU:

Office of the United Nations Environment Program (UNEP) in Brazil

* only participated in the 2 nd cycle

Sources: based on MMA, 2011 and MMA, 2016. 


\subsection{The status of the SCP field in Brazil}

Stemming from the recognition of the systemic socioenvironmental crisis by international actors, Agenda 21 is an important environmental policy instrument and may be considered one of the structuring internal governance units in the formation of the SCP field. Characterized by a variety of contradictory discourses and practices, both the concept of "sustainable development", where the main thing at stake is access to natural resources, and Agenda 21 have been criticized by a broad range of challenger civil society actors such as environmentalists. Much of the criticism surrounds the emphasis on ecological modernization, use of market-based instruments, and failure to deal with the root causes of environmental problems (DOYLE, 1998).

Since then, we have witnessed the legitimization of sustainability as the discursive matrix of sustainable development, concealing and reinforcing the political order (RODRIGUES, 2011; MEYER 2015) and conferring a state of "dynamic stability" on the sustainable development field as a whole.

In the case of SCP, the field emerged in 2003 with the launch of the Marrakech Process, inheriting part of the rhetoric and stability of the sustainable development field, and taking form in Brazil in 2007 as a consequence of state action after the country joined the Process. Thereafter, the institutionalization of the Steering Committee and cycles of the SCPAP are examples of internal governance units created by the state to reinforce the commitment of collective actors to the new field. Given the 'Russian doll'-nature of fields described by FLIGSTEIN and McADAM (2012), where fields are seen to be embedded in other fields, it can be said that the concept of SCP emerged from a larger field -the sustainable development field.

Box 1 shows that the country has indeed produced SCP policies, such as Law 12.349/2010, which deals with sustainable procurement, and Law 12.305/2010, which defines the National Waste Policy. Since the 1st Cycle of the SCPAP was only published after these instruments were regulated, these laws have little to do with the Plan, but rather give priority to the discursive matrix of sustainability that preceded them.

A review of the most commonly applied SCP policy instruments by Heiskanena et al. (2009) highlighted the following types of instruments: regulatory instruments, economic instruments, communication-based (including labeling) instruments, and voluntary and procedural instruments. Various studies have demonstrated how each of these different instruments can be used to promote sustainable consumption and production (STANISKIS, 2012; LOREK; BARBER; ONTHANK, 2013; SPANGENBERG, 2014).

However, the instruments outlined in the Implementation Report of the 1st Cycle of the SCPAP (MMA, 2014) are predominantly voluntary, followed by federal government actions that were already underway before the plan was elaborated. It could be said therefore that the majority of the actions highlighted in the Report would have occurred regardless of the SCPAP and are not the result of the Plan, but rather parallel initiatives that may have been reinforced by piecemeal actions promoted by the SCP Steering Committee. The reason for this is diverging interests among the actors in the field and 
power asymmetries between these actors - which becomes clear when we analyze their discourses, as demonstrated below.

\section{Sociological analysis of the discourses employed by social actors in} the field

The analysis was conducted in three stages: initial procedures, interpretation, and analysis.

The first stage consisted of the identification of information sources, comprising the following documents related to the National SCPAP published between 2011 and 2018: minutes of SCP Steering Committee meetings, minutes of intersectoral meetings, the SCPAPs (documents from the 1st and 2nd cycles), and the Evaluation Report of the 1st Implementation Cycle. The actors were classified as state or non-state according to their social role and the operationalization of the SAF theory. Elements of the discourse were identified and classified into dimensions and aspects using open thematic coding (GIBBS, 2009).

In the interpretation stage, we elaborated pre-analytical conjectures about the organization of the SCP in relation to the role of the state and non-state actors.

Finally, in the analysis stage, we explored the relationship between the discursive positions of the different social actors and the respective narrative configurations (what is discussed and how, conflicts and differences in positions) and semantic spaces (what is at stake).

\subsection{Discourses of the non-state actors}

Non-state actor participation in the elaboration of the two cycles of the SCPAP took place through intersectoral meetings, SCP Steering Committee meetings, and the public consultation on the Plan, constituting important spaces for the participation of these actors in this policy under development as stakeholders. The analysis of the minutes of the respective meetings reveals both converging and conflicting positions. In this regard, the findings show there is a convergence between the discourses of private sector actors and the consultants hired by the MoE to assist in the preparation of the SCPAP (Box 3). 
No Actor

MoE consultant for the preparation of 2nd Cycle of the SCPAP

\begin{tabular}{|c|c|c|}
\hline & of the SCPAP & $\begin{array}{l}\text { by the } \\
\text { MoE }\end{array}$ \\
\hline 2 & $\begin{array}{l}\text { MoE consultant for the } \\
\text { preparation of } 2 \text { nd Cycle } \\
\text { of the SCPAP }\end{array}$ & $\begin{array}{l}\text { Con- } \\
\text { sultant } \\
\text { hired } \\
\text { by the } \\
\text { MoE }\end{array}$ \\
\hline 3 & $\begin{array}{l}\text { Brazilian Packaging } \\
\text { Association - ABRE }\end{array}$ & $\begin{array}{l}\text { Private } \\
\text { sector }\end{array}$ \\
\hline 4 & $\begin{array}{l}\text { Representative of the } \\
\text { National Confederation } \\
\text { of Commerce - CNC and } \\
\text { Brazilian Supermarket } \\
\text { Association - ABRAS }\end{array}$ & $\begin{array}{l}\text { Private } \\
\text { sector }\end{array}$ \\
\hline 5 & $\begin{array}{l}\text { Representative of the } \\
\text { National Confederation } \\
\text { of Industry CNI }\end{array}$ & $\begin{array}{l}\text { Private } \\
\text { sector }\end{array}$ \\
\hline
\end{tabular}

Con-

sultant

\section{Type Contribution}

The Plan can help strengthen the implementation of sustainability initiatives in the country, particularly compliance with the commitments undertaken by the Brazilian government related to international agre ements. (...) We need to gradually progress towards a sustainable economy avoiding disruption of the private sector, $\ldots$ the joint construction process with the government is very important, because sometimes you work on a super-modern law and Brazil is champion in having a really good legislation, but is unable to implement it because it wasn't agreed across all the sectors involved. (...) The truth is the opposite happens: the private sector advances faster than the government but doesn't receive recognition in the form of incentives that the government could provide for these advances.

[presenting the results of a study of private sector expectations of engagement in the SCPAP] The definition and use of measurement methodologies and verification of sustainability criteria for products and services, encompassing various methods, including self-declaration, which would be an important step, instead of a broader certification process. referring to the guidelines of the SCPAP] Incentives and simpler licensing procedures for companies that have implemented an environmental management system/certification (ISO 14001), as a way of encouraging business to invest in environmental management systems, seek certification, and maintain the system with the aim of reducing the environmental impacts they cause.

(...) we often wait for formalization or legislation and we have the competence to do it. Some might call it self-declaration or even self-regulation. Because we have a lot of initiatives that end up becoming lost along the way and we sometimes lose the opportunity to do that.

The representative of the CNI (...) reaffirmed that the SCPAP can count on the support of the Confederation. With regard to life-cycle analysis, he observed that the idea of LCA is one thing and the application of the tool is another. While the former should be adopted, the latter should not appear as a demand because it is a complex and costly process for the industry. The representative of the CNI requested that the topic "increased product durability" be excluded, since the notion cannot or should not necessarily employed for all products. In some cases it could hinder innovation.

\section{Dimension \\ Aspects \\ Source}

Reformism, Minutes of the meeting of

Economic $\quad$ economic $\quad$ the SCPSC on $02 / \mathrm{Apr} / 18$

incentives (MMA, 2018, p. 47)

Economic

Economic

Minutes of the meeting of

the SCPSC on $02 / \mathrm{Apr} / 18$

(MMA, 2018, p. 48)

\begin{tabular}{l|l|l}
$\begin{array}{l}\text { Economic/ } \\
\text { Legal }\end{array}$ & $\begin{array}{l}\text { Deregu- } \\
\text { lation/ } \\
\text { economic } \\
\text { incentives }\end{array}$ & $\begin{array}{l}\text { Appendix III of the SCPAP. } \\
\text { MMA, 2011-b, p. } 105\end{array}$ \\
Legal & $\begin{array}{l}\text { Deregula- } \\
\text { tion }\end{array}$ & $\begin{array}{l}\text { Minutes of the meeting of } \\
\text { the SCPSC de 02/Apr/18 } \\
\text { (MMA, 2018, p. 52) }\end{array}$ \\
$\begin{array}{l}\text { Economic/ } \\
\text { Legal }\end{array}$ & $\begin{array}{l}\text { Cost reduc- } \\
\text { tion/Dere- } \\
\text { gulation }\end{array}$ & $\begin{array}{l}\text { Minutes of the meeting of } \\
\text { the SCPSC on 30/Mar/16 } \\
\text { (MMA, 2016, p.3) }\end{array}$ \\
\hline
\end{tabular}

gulation 


\begin{tabular}{|c|c|c|c|c|c|c|}
\hline No & Actor & Type & Contribution & Dimension & Aspects & Source \\
\hline 6 & $\begin{array}{l}\text { Representatives of Wal- } \\
\text { mart, Pão de Açúcar and } \\
\text { Carrefour }\end{array}$ & $\begin{array}{l}\text { Private } \\
\text { sector }\end{array}$ & $\begin{array}{l}\text { They describe various voluntary SCP initiatives that they implement and } \\
\text { highlight that how to communicate actions for sustainability developed } \\
\text { by industry and business to society is a challenge. }\end{array}$ & Legal & $\begin{array}{l}\text { Communi- } \\
\text { cation }\end{array}$ & $\begin{array}{l}\text { Minutes of a discussion } \\
\text { table on sustainable retail } \\
\text { related to the } 2 \text { nd cycle of } \\
\text { the SCPAP on } 11 / \text { Aug/2015 } \\
\text { (MMA, 2015, p. } 2 \text {-3) }\end{array}$ \\
\hline 7 & Instituto Akatu & $\begin{array}{l}\text { Civil } \\
\text { society }\end{array}$ & $\begin{array}{l}\text { [with regard to the SCPAP guidelines] Work on an economic, political } \\
\text { and institutional regulation plan, with a view to building or reshaping/ } \\
\text { adjusting these institutions to create a fiscal and economic/financial } \\
\text { regulatory framework that encourages a shift to SCP. }\end{array}$ & Economic & Regulation & $\begin{array}{l}\text { Appendix III of the SCPAP. } \\
\text { MMA, 2011, p. } 117\end{array}$ \\
\hline 8 & Individual & $\begin{array}{l}\text { Civil } \\
\text { society }\end{array}$ & $\begin{array}{l}\text { With regard to the implementation of the SCPAP, I suggest the invol- } \\
\text { vement of institutional actors that have greater capacity for political } \\
\text { articulation and influencing the economy, taking this issue to the heart } \\
\text { of the government, like the Executive Office of the President and } \\
\text { economic ministries. }\end{array}$ & Political & Regulation & $\begin{array}{l}\text { Appendix III of the SCPAP. } \\
\text { MMA, 2011, p. } 97\end{array}$ \\
\hline 9 & $\begin{array}{l}\text { Brazilian Society for } \\
\text { Ecological Economics }\end{array}$ & $\begin{array}{l}\text { Civil } \\
\text { society }\end{array}$ & $\begin{array}{l}\text { A SCPAP monitoring plan and respective performance indicators should } \\
\text { be presented. (...) The Plan is vague and/or omissive in relation to goals } \\
\text { and concepts. }\end{array}$ & $\begin{array}{l}\text { Technical and } \\
\text { scientific }\end{array}$ & $\begin{array}{l}\text { Transpa- } \\
\text { rency }\end{array}$ & $\begin{array}{l}\text { Appendix III of the SCPAP. } \\
\text { MMA, 2011-b, p. } 114\end{array}$ \\
\hline 10 & $\begin{array}{l}\text { Representative of the } \\
\text { Instituto Alana }\end{array}$ & $\begin{array}{l}\text { Civil } \\
\text { society }\end{array}$ & $\begin{array}{l}\text { Private sector regulation is vital. Advertising aimed at children is easier } \\
\text { to deal with because it has more appeal, but advertising aimed adults is } \\
\text { also overwhelming. You can't place all the responsibility on the consu- } \\
\text { mer. }\end{array}$ & Legal & Regulation & $\begin{array}{l}\text { Minutes of a discussion on } \\
\text { sustainable consumption for } \\
\text { the } 2 \text { nd cycle of the SCPAP } \\
\text { on } 12 / \text { Aug/2015 (MMA, } \\
2015 \text {, p. 4) }\end{array}$ \\
\hline 11 & $\begin{array}{l}\text { Representative of the } \\
\text { Brazilian Institute for } \\
\text { Consumer Protection - } \\
\text { IDEC }\end{array}$ & $\begin{array}{l}\text { Civil } \\
\text { society }\end{array}$ & $\begin{array}{l}\text { (...) There won't be sustainable consumption without sustainable } \\
\text { production (...). We have a plan [the SCPAP] which is almost entirely } \\
\text { based on voluntary initiatives. The state is neglecting its role as for- } \\
\text { mulator of regulatory and enforcement policy. I have my reservations } \\
\text { about a plan that looks like a showcase for good practices. (...) The role } \\
\text { of the state is not to adhere to a commitment, the role of the state is to } \\
\text { regulate and enforce and define policies that encourage new patterns of } \\
\text { consumption and production. I'm talking about a new consumption and } \\
\text { production logic (...). It is a little kind to see them as opposite sides from } \\
\text { a same coin. }\end{array}$ & Legal & Regulation & $\begin{array}{l}\text { Minutes of the first meeting } \\
\text { of the SCPSC de } 22 / \\
\text { Nov/2011 }\end{array}$ \\
\hline 12 & $\begin{array}{l}\text { Representative of the } \\
\text { United Nations Environ- } \\
\text { ment Program - UNEP }\end{array}$ & $\begin{array}{l}\text { Repre- } \\
\text { sen- } \\
\text { tative } \\
\text { of the } \\
\text { UN }\end{array}$ & $\begin{array}{l}\text { The preliminary draft [of the } 2 \text { nd Cycle of the SCPAP] talks little about } \\
\text { public policy or how to implement the proposals. }\end{array}$ & $\begin{array}{l}\text { Political/ } \\
\text { Technical and } \\
\text { scientific }\end{array}$ & $\begin{array}{l}\text { Regulation/ } \\
\text { Transpa- } \\
\text { rency }\end{array}$ & $\begin{array}{l}\text { Minutes of a discussion } \\
\text { tables on sustainable } \\
\text { consumption for the } 2 \text { nd } \\
\text { cycle of the SCPAP on 12/ } \\
\text { Aug/2015 (MMA, 2015, } \\
\text { p. 3) }\end{array}$ \\
\hline
\end{tabular}

Source: authors' elaboration based on the cited sources 
The discourses of the consultants hired by the MoE portray a "reformist" view of SCP policies (GEELS et al., 2015) without any break with traditional business models and progressing towards the so-called "sustainable economy". In excerpt [1], the narrative configuration revolves around laws that are not implemented due to lack of adherence by the private sector. The semantic space in question is the power of veto held by this actor, placing it in a position of social dominance as an incumbent actor, while at the same time reaffirming that the private sector is advancing faster than the public sector without receiving anything in return. This neoliberal discourse also appears in excerpt [2], which declares that sustainability is "an important step" to be taken, without clarifying why and for whom. The adoption of selfdeclaratory instruments is reinforced by representatives of the business sector, as illustrated by excerpt [4] from a representative of the supermarket sector. Others go even further, such as the representative of the packaging industry who calls for "incentives and simpler licensing procedures" as if licensing was merely a bureaucratic formality (excerpt [3]).

In excerpt [5], a representative of the industrial sector opposes measures to ensure increased product durability and promote product life cycle analysis by the industry for financial reasons, while the supermarket sector (excerpt [6]) is concerned about communicating actions for sustainability developed by industry and business to society, suggesting that what is at stake is the economic sustainability of its operations rather than gross reductions in material consumption.

In excerpts [7], [8] and [11], civil society actors emphasize the importance of government regulation in the economic, political, and institutional spheres through institutional actors that have greater capacity for political articulation and influencing the economy, while in excerpt [10] they show concerns with "overwhelming advertising". Instituto Alana and IDEC (excerpts [10] and [11], respectively) suggest that producers should assume greater responsibility than consumers and that voluntary initiatives are not enough, emphasizing the role of the government in defining policy, regulation, and enforcement - a position that is shared by the representatives of the UNEP in excerpt [12]. The narrative configuration reveals diverging interests among civil society and the private sector in relation to the state's role in regulating/deregulating production. What is at stake in this clash of interests are "degrees of freedom" to produce, advertise, and sell products.

There is also a convergence between the discourses of civil society and the UNEP, which in turn diverges from those of the private sector and consultants. Clearly, the private sector represents a group of incumbent actors who hold greater economic power and adopt the reformist discourse of "bend rather than break" based on self-regulatory initiatives, while civil society organizations challenge the stability of the field, pushing for greater state action as a way of bringing priorities on the economic agenda in line with socioenvironmental interests. From the point of view of SAF theory, this means that the interests of incumbent groups tend to prevail in the configuration of the field, promoting merely adaptive changes based on eco-efficiency and self-regulation and thus failing to restrict access to natural resources and markets.

\subsection{Discourses of the state actors}

The position of the MoE is rather ambiguous. On the one hand, the officials heading the SIAEC recognize that formalization of SCP policy should be the function of the state, while those at the DSCP fear that a clash with politically and economically stronger incumbent actors could produce mediocre policies (Box 4). 


\begin{tabular}{|c|c|c|c|c|c|c|}
\hline No. & Actor & $\begin{array}{l}\text { Social } \\
\text { role }\end{array}$ & Contribution & Dimension & Aspects & Source \\
\hline 13 & Director of SIAEC/MoE & $\begin{array}{l}\text { Federal } \\
\text { govern- } \\
\text { ment }\end{array}$ & $\begin{array}{l}\text { [answering a question about the risk of the SCPSC being extinct] } \\
\text { We are not talking about the political will of a government here. The } \\
\text { truth is it's an agreement between countries of which we are part. } \\
\text { So the idea is that each country had their own plan, so this here will } \\
\text { perpetuate with a change of government. }\end{array}$ & Political & $\begin{array}{l}\text { Gover- } \\
\text { nance }\end{array}$ & $\begin{array}{l}\text { Minutes of the meeting of } \\
\text { the SCPSC on 02/Apr/18 } \\
\text { (MMA, 2018, p. 52) }\end{array}$ \\
\hline 14 & Director of SIAEC/MoE & $\begin{array}{l}\text { Federal } \\
\text { govern- } \\
\text { ment }\end{array}$ & $\begin{array}{l}\text { (...) we understood that if you work, work, work and don't influen- } \\
\text { ce public policy, you don't influence bills, you end up missing the } \\
\text { "train of history" because a bunch of politicians go and made a law } \\
\text { completely contrary to everything we have been working so hard to } \\
\text { realize. So I think it's an important issue to work in parallel or jointly } \\
\text { on. The CNI is always working on this. The CBIC as well. So I think } \\
\text { it's something that can't be overlooked. (...) We have a key ally in the } \\
\text { Congress, the Environmental Parliamentary Front, which is the cau- } \\
\text { cus with the highest number of deputies and senators; and it works } \\
\text { (...). We have to remember that after we create a national policy we } \\
\text { have to regulate it and you have to create the same piece of legisla- } \\
\text { tion at state level. That's why the state environmental parliamentary } \\
\text { fronts were created. They already exist and are working together with } \\
\text { the national front. }\end{array}$ & Political & Regulation & $\begin{array}{l}\text { Minutes of the meeting of } \\
\text { the SCPSC on 02/Apr/18 } \\
\text { (MMA, 2018, p. 88) }\end{array}$ \\
\hline 15 & $\begin{array}{l}\text { Coordinator of DSCP/ } \\
\mathrm{MoE}\end{array}$ & $\begin{array}{l}\text { Federal } \\
\text { govern- } \\
\text { ment }\end{array}$ & $\begin{array}{l}\text { [regarding the creation of SCP policies] Algumas institucionalizações } \\
\text { may constrain [policies] (...). What will we gain by creating a [SCP] } \\
\text { policy? It provides a certain degree of visibility, a certain degree } \\
\text { of institutional security, but I don't know what the content of this } \\
\text { policy will be. When we try to institute this policy within a context } \\
\text { of correlation of forces and political and economic powermongering, } \\
\text { compared to other bigger policies, we could end up with a mediocre } \\
\text { outcome. (...) I reckon if we manage to get the necessary resources } \\
\text { from the multiannual plan we can do alright. }\end{array}$ & $\begin{array}{l}\text { Economic/ } \\
\text { Legal }\end{array}$ & $\begin{array}{l}\text { Financial } \\
\text { resources/ } \\
\text { Communi- } \\
\text { cation }\end{array}$ & $\begin{array}{l}\text { Interview given on } 18 / \\
\text { Oct/18 }\end{array}$ \\
\hline
\end{tabular}

Source: authors' elaboration based on the cited sources 
For the official from the MoE, the SCPAP seeks to articulate initiatives stemming from an international agreement within the potential limits of national political articulation, which is strongly influenced by incumbent actors represented by private sector organizations that have the power to influence the legislative agenda (excerpts [13] and [14]). From the point of view of SAF theory, the state is not one single player, but rather a complex set of multiple actors characterized by internal divisions and distinct political interests. In this sense, it is evident from the official's discourse in excerpt [15] that the implementation of a more "liberal" SCP agenda based on voluntary instruments and sectoral agreements was a preferred alternative to inaction or even retrograde steps in the socioenvironmental agenda.

Finally, another point worth highlighting from the analysis of the SCPAP is the time interval between the launch of the Marrakech Process (2003), Brazil's enrollment in the process (2007), and the publication of the main products: the 1st Cycle of the SCPAP (2011) and the 2nd Cycle (which, as mentioned above, had yet to be published at the date of publication of this article). Here, the concept of non-decision making (BARHRACH; BARATZ, 1963) helps us understand the reasons for such a long interval: (a) the low priority given to the preparation of the SCPAP by both incumbent actors and the state; (b) conflicting interests, particularly economic interests; and (c) the political and institutional context, in particular the 2008 global financial crisis and political crisis in Brazil that began in 2015 leading to the impeachment of Dilma Rousseff and a staffing shake-up in the MoE.

\section{Final considerations}

There is much discussion surrounding SCP policy on the world stage, stemming from the recognition by states and civil society of the limits to the capacity of ecosystems to sustain continuous economic growth based on ever-increasing material consumption and production. However, there is a lack of consensus over this issue because changing production models affects incumbent actors in the economic field. As signatory to these international agreements, Brazil has undertaken a commitment to formulate policies to encourage a shift to more sustainable patterns of production and consumption.

The findings of this study reveal the slow pace of progress on the development of Brazil's SCPAP. The probable reason for this is that incumbent actors have striven to present reformist alternatives in the political, economic, legal, and technical and scientific spheres in order to maintain their position in the field. In political game playing, it is those who hold the most power who benefit most from the resulting policies, not necessarily those who maintain the rule of law. The exercise of power occurs in a number of ways, including the suppression of the demands of challenger actors such as environmentalists and social movements and the obfuscation of potential disputes.

In the case of Brazil's national SCPAP, the fact that the MoE was tasked with its preparation clearly reveals the government's ideological position: sustainability is an environmental issue and not a cross-cutting one as challenger actors suggest. That is why 
the Ministry of Planning or the Executive Office of the President, for example, were not charged with its preparation.

This study goes some way towards charting the interplay between opposing political forces in the development of national SCP policies. On this point, field theory (FLIGSTEIN; MCADAM, 2012) showed itself to be an important tool for revealing conflicting interests and actor movement within the field. Far from suggesting the dichotomous polarization of social actors in the field, it helped reveal that, despite the inherent challenges of the political game, progress has been made. Actors have made positive contributions and other agendas may emerge as more favorable conditions are created for improving the autonomy of dominated social actors.

Another contribution of this study is the establishment of a methodological association between field theory (FLIGSTEIN and MCADAM, 2012) and sociological discourse analysis (CONDE, 2009), bearing in mind that both techniques have the same philosophical and epistemological underpinnings, being essentially qualitative, critical, subjectivist, and historically framed.

Sociological discourse analysis reveals aspects that have prevented the emergence of agendas expected by society, such as the influence of the prevailing interests of the private sector, the main beneficiary of the status quo. These aspects include the regulation/ deregulation of consumption and production systems, business communication strategies, necessary investment, and the level of transparency of state policy and private initiatives.

The ultimate aim of SCP policy should be to promote a shift from the current state of unsustainability towards an alternative based not only on eco-efficiency, but also on reducing the deficit between our ecological footprint and biocapacity. In practice, the struggle between incumbent and challenger actors in the SAF has resulted in reformist alternatives, such as deregulation and economic incentive instruments, and limited transparency in private sector initiatives.

Future research should be undertaken to explore how the private sector has incorporated the SCP discourse and practices into social accountability processes through corporate social responsibility instruments 


\section{REFERENCES}

ALENCAR, J. L. O.; REYES JUNIOR, E. Análise da rede de relações e sua influência nas políticas públicas de turismo. Texto para Discussão no. 2355. Instituto de Pesquisa Econômica Aplicada. Rio de Janeiro: IPEA, 2017.

BARBALHO, F. A. Emergência de um campo de ação estratégica: o caso da política pública sobre dados abertos. Tese (Doutorado em Administração). Faculdade de Economia, Administração e Contabilidade. Universidade de Brasília. 2014.

BARBER, J. Mapping the movement to achieve sustainable production and consumption in North America. Journal of Cleaner Production 15, 499-512, 2007.

BARHRACH, P. e BARATZ, M. Decisions and non-decisions: an analytical framework. American Political Science Review, 57, 1963.

BELEI, R. A.; GIMENIZ-PASCHOAL, S. R., NASCIMENTO, E. N., MATSUMOTO, P. H. V. R. O uso de entrevista, observação e videogravação em pesquisa qualitativa. Cadernos de Educação. Pelotas: FaE/PPGE/UFPel, v.30, p. 187 - 199, janeiro/junho 2008.

BOLIS, I.; MORIOKA, S. N.; SZNELWAR, L. I. When sustainable development risks losing its meaning. Delimiting the concept with a comprehensive literature review and a conceptual model. Journal of Cleaner Production vol. 83, no. 2014.

BORCHARDT, M. A.; SIENA, O. Discurso Organizacional sobre Sustentabilidade no Contexto do Complexo Hidrelétrico do Rio Madeira. Revista Espacios 37, 32, 2016.

CALADO, S.; FERREIRA, S. C. Análise de documentos: método de recolha e análise de dados. Metodologia de Investigação. DEFCUL. 2004-2005.

CANDIDO, S. E. A.; SOULÉ, F. V; SACOMANO NETO, M. The Emergence of Solidarity Recycling $\square$ in Brazil: Structural Convergences and Strategic Actions in Interconnected Fields. Organization \& Environment p. 1-23. 2018

CAVALCANTI, C. Sustentabilidade: mantra ou escolha moral? Uma abordagem ecológico-econômica. Revista de Estudos Avançados vol. 26, no. 74, 2012.

CNUMAD - Conferência das Nações Unidas sobre o Meio Ambiente e Desenvolvimento (1992: Rio de Janeiro). Agenda 21. Brasília: Câmara dos Deputados, Coordenação de Publicações, 1995 , $472 \mathrm{p}$.

COELHO, A. L.; GODOI, C. K. Coerência entre o Discurso Institucional e o Discurso Midiático sobre a Sustentabilidade. Revista de Gestão Social e Ambiental, 4, 69-88, 2010.

COELHO, A. L.; GODOI, C. K.; COELHO, C.; SERRANO, P. A. Análise do discurso da sustentabilidade em uma empresa do setor de energia elétrica. Revista Gestão e Conexões, 1, 122-158, 2012. 
CONDE, F. G. del A.. Análisis sociológico del sistema de discursos. Cuadernos Metodológicos 43. Madrid: CIS - Centro de Investigaciones Sociológicas, 2009.

CSEH, A. Mapeamento do campo da gestão de resíduos orgânicos na cidade de São Paulo. Dissertação (Mestrado em Ciências) - Programa de Pós-Graduação em Sustentabilidade, Escola de Artes, Ciências e Humanidades, Universidade de São Paulo, 2019.

DOLAN, P. The Sustainability of "Sustainable Consumption". Journal of Macromarketing vol. 22, no. 2, p. 170-81, 2002.

DOYLE, T. Sustainable development and Agenda 21: The secular bible of global free markets and pluralist democracy. Third World Quarterly, vol. 19, no. 4, 1998.

DRIESSEN, P. P. J.; DIEPERINK, C.; VAN LAERHOVEN, FR.; RUNHAAR, H. A. C.; VERMEULEN, W. J. V. Towards a Conceptual Framework for The Study of Shifts in Modes of Environmental Governance - Experiences From The Netherlands. Environmental Policy and Governance 22, p. 143-160, 2012.

DUARTE, J. Entrevista em profundidade. In: DUARTE, J.; BARROS, A. (Org.) Métodos e técnicas de pesquisa em comunicação. 2. ed. São Paulo: Atlas, 2006. p. 62-83.

FERREIRA, V. F. M. Resíduos de Equipamentos Eletroeletrônicos: Um Estudo Do Campo De Ação Estratégica No Contexto Brasileiro. 2018. Dissertação (Mestrado em Ciências Ambientais). Instituto de Energia e Ambiente. Universidade de São Paulo. 2018.

FLIGSTEIN, N., McADAM, D. A Theory of Fields. Oxford: Oxford University Press, 2012.

GEELS, F. W., MCMEEKIN, A., MYLAN, J., SOUTHERTON, D. A critical appraisal of Sustainable Consumption and Production research: The reformist, revolutionary and reconfiguration positions. Global Environmental Change, 34, 2015.

GIBBS, G. Análise de dados qualitativos. Porto Alegre Artmed, 2009

GODOI, C. K.; MASTELLA, A. S.; UCHÔA, A. G. F. Integração metodológica entre grupo de discussão e análise sociológica do discurso: um caso exemplificador sobre o discurso feminino acerca do consumo da beleza. Revista Eletrônica de Administração, vol. 24, no 1, p. 30-60, 2018.

GODOY, A. M. G. Teoria dos campos e políticas ambientais locais. Desenvolvimento e Meio Ambiente, Curitiba, n. 24, p. 119-136, Jul/Dez. 2011

GOLDSTONE, J. A.; USEEM, B. Putting values and institutions back into the theory of strategic action fields. Sociological Theory, v. 30, n. 1, p. 37-47, 2012.

GONÇALVES-DIAS, S. L. F, MOURA, C., HOYOS, A. Beyond Green Innovation: The Next Step. RISUS. Journal on Innovation and Sustainability, v.2, n.1, 2011.

HEISKANENA, E.; BROHMANNB B.; SCHÖNHERRB N.; AALTOA K. Policies to Promote Sustainable Consumption: Framework For a Future-Oriented Evaluation. Future of the Consu- 
mer Society, 28-29, Tampere, Finland, 2009.

JACKSON, T.; MICHAELIS, L. Policies for sustainable consumption: A Report to the sustainable development commission. 2003.

JONQUERES, F. P. Un diario visto con lupa: discurso ecológico en la prensa. Comunicación y Pluralismo vol. 1, no. 6, p. 9-33, 2008.

KALMYKOVA, Y., ROSADO, L., PATRICIO, J. 2016. Resource consumption drivers and pathways to reduction: economy, policy and lifestyle impact on material flows at the national and urban scale. Journal of Cleaner Production 132, 70-80.

LIU, Y.; QU, Y.; LEI, Z., JIA, H. Understanding the Evolution of Sustainable Consumption Research. Sustainable Development vol. 25, no. 5, 2017.

LOREK, S.; BARBER, J.; ONTHANK, K. (ed.). Global and Regional Research on Sustainable Consumption and Production Systems: Achievements, Challenges and Dialogues. Workshop Report of the Global Research Forum on Sustainable Production and Consumption. Rio de Janeiro, 2013.

MANDAI, S. S. A Comissão Nacional da Biodiversidade (CONABIO) como um campo ambiental no Brasil? XIX Encontro Internacional sobre Gestão Empresarial e Meio Ambiente. São Paulo, 2017.

MARQUES, E. As políticas públicas na ciência política. In: Marques, E. e Faria, C. (org.). A política pública como campo multidisciplinar. São Paulo, Editora Unesp, 2013.

MAXWELL, J. A. Qualitative Research Design: An Interactive Approach. SAGE Publications Inc. Thousand Oaks, 2012.

MEYER, G. da C. A sustentabilidade em questão: paradigma ou matriz discursiva? Dissertação de Mestrado. Escola de Artes, Ciências e Humanidades, Universidade de São Paulo. São Paulo, 2015.

MMA - MINISTÉRIO DO MEIO AMBIENTE. Ata de reunião do CGPCS. Brasília, DF, 30/ $\operatorname{mar} / 2016$.

. Ata de reunião do CGPCS. Brasília, DF, 02/abr/2018.

. Plano de Ação para Produção e Consumo Sustentáveis - PPCS 1‥ Ciclo. Brasília, DF, 2011.

. Plano de Ação para Produção e Consumo Sustentáveis - PPCS 2ํ․ Ciclo. Documento para consulta pública. Brasília, DF, 2016.

. Relatório do Primeiro Ciclo de Implementação do Plano de Ação para Produção e Consumo Sustentáveis - PPCS. Brasília, DF, 2014. 
MONT, O.; PLEPYS, A. Sustainable consumption progress: should we be proud or alarmed? Journal Cleaner Production no. 16, p. 531-537, 2007.

MOULTON, S.; SANDFORT, JR. The strategic action field framework for policy implementation research. The Policy Studies Journal, Vol. 45, No. 1, 2017

PEREY, R. Making sense of sustainability through an individual interview narrative. Journal of Culture and Organization vol. 21, no. 2, 2015.

PORTILHO, F.; RUSSO, F. F. Processo Marrakech - o consumo sustentável visto pelos organismos internacionais. In: Encontro Nacional da ANPPAS, 2008, Brasília. Anais eletrônicos... Brasília: Associação Nacional de Pós-Graduação e Pesquisa em Ambiente e Sociedade, 2008.

PORTILHO, M. F. F. Sustentabilidade Ambiental, consumo e cidadania. São Paulo: Cortez, 2005.

RAM, V. G.; MAHALINGAM, A.; KALIDINDI, S. N. Institutional struggle behind the diffusion of construction and demolition waste recycling practices. Working Paper Proceedings. 15th Engineering Project Organization Conference and 5th International Megaprojects Workshop. Stanford Sierra Camp, California. Jun 5-7, 2017.

REISCH, L. A., THØGERSEN, J. (Eds.). Handbook of Research on Sustainable Consumption, Cheltenham, UK: Edward Elgar Publishing, 2015.

RODRIGUES, A. M. . A Matriz Discursiva sobre o. In: Ana Fani A Carlos, Marcelo Lopes de Souza, Maria Encarnação Sposito. (Org.). A produção do Espaço Urbano: agentes, processos, escalas e desafios. São Paulo: Editora Contexto, 2011, p. 207-230.

RODRÍGUEZ VICTORIANO, J. M. Los Discursos Sobre el Medio Ambiente en la Sociedad Valenciana (1996-2000). Estudio General Facultad de Ciencias Sociales. Departamento de Sociología y Antropología Social, Universidad de Valencia, 2003.

SALDO, P. Entrevista sobre o Plano de Ação para Produção e Consumo Sustentáveis. Entrevista concedida a Érico Pagotto. Brasília, 18 out. 2018.

SCHOON, N.; SEATH, F; JACKSON, L. One Planet Living - The case for Sustainable Consumption and Production in the Post - 2015 development agenda. Bond/ Bioregional Paper. United Kingdom, 2013.

SEYFANG, G. Consuming Values and Contested Cultures: A Critical Analysis of the UK Strategy for Sustainable Consumption and Production. Review of Social Economy, Vol. 62, no. 3, 2004.

SILVA JUNIOR, R. D.; FERREIRA, L. C.; LEWINSOHN, T. M. Entre hibridismos e polissemias: para uma análise sociológica das sustentabilidades. Revista Ambiente e Sociedade v. 18, n. 4, p. 35-54, 2015.

SPANGENBERG, J. H. Institutional change for strong sustainable consumption: sustainable consumption and the degrowth economy. Sustainability: Science, Practice \& Policy, Vol 10, no. $1,2014$. 
STANISKIS, J. K. Sustainable consumption and production: how to make it possible. Clean Techn Environ Policy no. 14, p. 1015-1022, 2012.

STERN, P. C. Toward a coherent theory of environmentally significant behaviour. Journal of Social Issues vol. 56, no. 3, p. 407-424, 2000.

THØGERSEN, J. Unsustainable Consumption: Basic Causes and Implications for Policy. European Psychologist Vol. 19, no. 2, p.84-95, 2014.

WANG, C.; GHADIMI, P.; LIM, M. K.; TSENG, M. L. A literature review of sustainable consumption and production: A comparative analysis in developed and developing economies. Journal of Cleaner Production vol. 206, no. 1, 2019.

WWF. Living Planet Report 2014: species and spaces, people and places. Gland, Suiça. Disponível em http://www.panda.org. Acesso em 3 jun 2016. 
Érico Luciano Pagotto

$\square$ erico.pagotto@fatec.sp.gov.br

ORCiD: https://orcid.org/0000-0002-2348-623X
Submitted on: 19/02/20199

Accepted on: 28/02/2020

2020;23:e00271

\section{Sylmara Lopes Francelino Gonçalves-Dias}

๑sgdias@usp.br

ORCiD: https://orcid.org/0000-0001-6326-2129

How to cite: PAGOTTO, E. L.; GONÇALVES-DIAS, S. L. F. SUSTAINABLE CONSUMPTION AND PRODUCTION FROM A STRATEGIC ACTION FIELD PERSPECTIVE. Ambiente \& Sociedade. São Paulo, v. 23, p. 1-22, 2020. 


\title{
PRODUÇÃO E CONSUMO SUSTENTÁVEIS: UM ESTUDO À LUZ DA TEORIA DE CAMPOS DE AÇÃO ESTRATÉGICA
}

\author{
Érico Luciano Pagotto \\ Sylmara Lopes Francelino Gonçalves-Dias
}

São Paulo. Vol. 23, 2020

Artigo Original

\begin{abstract}
Resumo: Este artigo analisa o processo de construção de políticas públicas de produção e consumo sustentável no Brasil após o ingresso do país no Processo de Marraquexe, em 2003. A partir da teoria de campos de ação estratégica, procurou-se analisar a emergência deste campo, suas características e seu estado por meio da ação coletiva de seus principais atores sociais com suas ações, interesses e disputas. Como material empírico para análise foram utilizados os planos desenvolvidos no período, as atas de reunião, os documentos lançados à consulta pública, as respostas fornecidas pela sociedade civil após a consulta, além de entrevistas em profundidade. Foi possível constatar que uma série de obstáculos vêm ocasionando atrasos aos avanços da política de produção e consumo sustentável em função de disputas entre atores incumbentes e desafiantes.
\end{abstract}

Palavras-chave: sustentabilidade, políticas públicas, consumo, campos de ação estratégica.

Como citar: PAGOTTO, E. L.; GONÇALVES-DIAS, S. L. F. PRODUÇÃO E CONSUMO SUSTENTÁVEIS: UM ESTUDO À LUZ DA TEORIA DE CAMPOS DE AÇÃO ESTRATÉGICA. Ambiente $\boldsymbol{\&}$ Sociedade. São Paulo, v. 23, p. 1-22, 2020. 


\title{
PRODUCCIÓN Y CONSOMO SOSTENIBLE: UN ESTUDIO A PARTIR DE LA TEORÍA DE CAMPOS DE ACCIÓN
}

\author{
Érico Luciano Pagotto \\ Sylmara Lopes Francelino Gonçalves-Dias
}

São Paulo. Vol. 23, 2020

Artículo original
Resumen: Este artículo analiza el proceso de construcción de políticas públicas de producción y consumo sostenible en Brasil tras el ingreso del país en el Proceso de Marrakech, en 2003. A partir de la teoría de campos de acción estratégica, se buscó analizar la emergencia de este campo, sus características y su estado por medio de la acción colectiva de sus principales actores sociales con sus acciones, intereses y disputas. Como material empírico para análisis se utilizaron los planes desarrollados en el período, las actas de reunión, los documentos lanzados a la consulta pública, las respuestas proporcionadas por la sociedad civil tras la consulta, además de entrevistas en profundidad. Fue posible constatar que una serie de obstáculos vienen ocasionando retrasos a los avances de la política de producción y consumo sostenible en función de disputas entre actores incumbentes y desafiantesbejassinaguijón y los valores sociales y culturalesatribuidos a esaactividad.

Palabras-clave: sostenibilidad, políticas públicas, consumo, campos de acción estratégica

Como citar: PAGOTTO, E. L.; GONÇALVES-DIAS, S. L. F. Modelo teórico para el análisis interdisciplinario de las actividades humanas: La meliponicultura como actividad promotora de la sostenibilidad. Ambiente $\&$ Sociedade. São Paulo, v. 23, p. 1-22, 2020. 